ASIMETRIS: JURNAL PENDIDIKAN MATEMATIKA DAN SAINS

$$
\text { p-ISSN } 2721 \text { - 8724, e-ISSN } 2722 \text { - } 0214
$$

Website Jurnal: http://journal.umuslim.ac.id/index.php/asm/

\begin{tabular}{r|l} 
Info Artikel: & Direvisi pada 20 Oktober 2021 \\
Disubmit pada 11 Oktober 2021 & Diterima pada 25 Oktober 2021 \\
Direview pada 18 Oktober 2021 & Tersedia secara daring pada 28 Oktober 2021 \\
\hline
\end{tabular}

\title{
PENGARUH PENDEKATAN SAINTIFIK TERHADAP KEMAMPUAN BERFIKIR KRITIS PESERTA DIDIK PADA POKOK MATERI FUNGSI KOMPOSISI
}

\author{
Icut Mawarni ${ }^{1}$, Yessi Kartika², Rahmi Hayati \\ 1,2,3 Pendidikan Matematika Universitas Almuslim Bireuen, Aceh, Indonesia \\ Alamat email: ctmwrnii46@gmail.com
}

\begin{abstract}
ABSTRAK. Tujuan penelitian ini adalah untuk melihat pengaruh pendekatan saintifik terhadap kemampuan berfikir kritis siswa lebih akan lebih baik dari pada menggunakan pembelajaran konvensional di SMA Negeri 1 Bireuen. Penelitian ini merupakan penelitian kuantitatif dengan jenis penelitian eksperimen semu (quasi experimental). Desain yang digunakan dalam penelitian ini adalah pretest posttes control group design. Adapun yang menjadi populasi dalam penelitian ini adalah siswa X IPA SMA Negeri 1 Bireuen. Teknik pengambilan sampel dalam penelitian ini adalah purposive sampling, kelas yang terambil yaitu kelas X IPA E sebagai kelas ekaperimen yang berjumlah 30 orang siswa dan X IPA F sebagai kelas kontrol yang berjumlah 30 orang siswa. Teknik pengumpulan data pada penelitian ini berupa tes dengan bentuk soal essay yang terdiri dari tes awal dan tes akhir. Berdasarkan hasil analisis data yang telah dilakukan, pengaruh pendekatan saintifik terhadap kemampuan berfikir kritis siswa pada materi pokok fungsi komposisi lebih baik dari pada peningkatan pembelajaran materi pokok fungsi komposisi melalui pembelajaran konvensional di SMA Negeri 1 Bireuen.
\end{abstract}

Kata kunci: Fungsi Komposisi, Kemampuan Berfikir Kritis, Pendekatan Saintifik.

ABSTRAK. Therefore, the researcher conducted a study with an approach to the influence of a scientific approach on students' critical thinking skills on the composition of function material at SMA Negeri 1 Bireuen. The purpose of this study was to see the increasing influence of the scientific approachon students' critical thinking skils that would be better than the use of conventional learning at SMA Neger 1 Bireuen. This research is quantitative research with the type of quasi-experimental research. The desidgn used in this study was a pretest posttest control group design. The population in this study were students of X IPA SMA Negeri 1 Bireuen. The sampling technique in this study is purposive sampling. the class taken is class $X$ IPA E as an experimental class which collects 30 students and XIPA $F$ as a control class which collects 30 students. The data collection technique in this study was in the form of a test in the form of an essay question consisting of an initial test and a final test. Based on the data analysis that has been carried out, the effect of the scientific approach on students' critical thinking skills on the subject matter of composition quality is better than increasing the learning of compositional subject matter through conventional learning at SMA Negeri 1 Bireuen.

Keyword: Composition Function, Critical Thinking Ability, Scientific Approach

\section{PENDAHULUAN}

Pelaksanaan pembelajaran matematika di SMA saat ini masih memiliki kekurangan yaitu dengan adanya masalah-masalah yang muncul. Salah satu masalah yang dihadapi adalah masalah lemahnya proses pembelajaran yang dilakukan sehingga membuat peserta didik kurang didorong untuk mengembangkan kemampuan berpikir.

Berdasarkan hasil pengamatan serta wawancara dengan salah satu guru matematika disekolah SMAN 1 Bireuen mengatakan bahwa Peserta didik kurang aktif dalam proses belajar berdiskusi, berpendapat dan bertanya, Seringkali 
pertanyaan yang diajukan peserta didik juga belum menunjukkan pertanyaan-pertanyaan kritis yang mengarah pada pertanyaan menganalisis pendapat yang berkaitan terhadap materi yang sedang dipelajari misalnya materi Fungsi Komposisi. Menurut (Khaulah \& Novianti, 2019) " Langkah-langkah pembelajaran yang harus dilakukan supaya tujuan pembelajaran tercapai dengan menerapkan model pembelajaran."

Pada saat proses pembelajaran berlangsung, peserta didik kurang menanamkam konsep fungsi komposisi yang baik, sehingga kemampuan berpikir kritis pada peserta didik tidak berkembang dengan baik juga. Salah satu penyelesaian yang dapat dilakukan untuk menyelesaikan permasalahan tersebut adalah dengan melakukan penerapan pendekatan saintifik. Pendekatan saintifik harus diterapkan pada pembelajaran karena berhubungan dengan penerapan kurikulum saat ini.

Beberapa hasil penelitian menyatakan bahwa pendekatan saintifik dapat mempengaruhi kemampuan berfikir kritis siswa yaitu, penelitian yang dilakukan oleh (Pratiwi et al., 2014) yaitu dalam penerapan pendekatan saintifik pada pembelajaran dapat mempengaruhi peningkatan keterampilan berpikir kritis siswa sebesar 28,23\% dengan perhitungan sebesar 0,78 . Berdasarkan beberapa kajian tentang pendekatan saintifik diatas, maka peneliti mengkaj tentang Pengaruh Pendekatan Saintifik Terhadap Kemampuan Berfikir Kritis Peserta Didik Pada Pokok Bahasan Fungsi Komposisi kelas X SMAN 1 Bireuen.

\section{METODE PENELITIAN}

Pendekatan yang diterapkan pada penelitian ini adalah pendekatan kuantitatif. Menurut (Sugiyono, 2011) metode penelitian ini menggunakan metode penelitian kuantitatif karena data dari penelitian di analisis dengan menggunakan statistik dan berupa angka- atau pun nilai. Adapun jenis penelitian yang digunakan dalam penelitian ini adalah eksperimen semu (quasi experimental) dengan tujuan untuk melihat pengaruh dari suatu perlakuan. Menurut (Syaodih, 2014) "pada dasarnya eksperimen semu (quasi experimental) sama dengan eksperimen murni, yang membedakan pada pengontrolan variabel dilakukan hanya pada satu variabel saja, yaitu variabel yang dipandang paling unggul.

Sesuai dengan jenis penelitian yang diharapkan, maka peneliti memilih salah satu desain penelitian yang tepat untuk dilaksanakan dalam penelitian ini yaitu Nonequivalent Control Group Design. Dalam desain ini, terdapat dua kelompok yaitu kelompok kelas eksperimen dan kelompok kelas kontrol. Kedua kelompok akan diberikan pretest untuk mengetahui keadaan awal. Selanjutkan kelompok kelas eksperimen diberi treatment berupa dengan pendekatan saintifik, sedangkan kelompok kontrol diberi pembelajaran yang biasa guru gunakan seperti pembelajaran konvensional. Setelah diberi treatment kedua kelompok diberi posttest untuk mengetahui keadaan akhir siswa. Adapun rancangan penelitian Nonequivalent Control Group Design modifikasi sebagai berikut:

Tabel 2.1 Nonequivalent Control Group Design

\begin{tabular}{lccc}
\hline \multicolumn{1}{c}{ Kelompok } & $\begin{array}{c}\text { Pre- } \\
\text { Test }\end{array}$ & Treatment & $\begin{array}{c}\text { Post- } \\
\text { Test }\end{array}$ \\
\hline Kelas Eksperimen & $\mathrm{O}_{1}$ & $\mathbf{X}$ & $\mathrm{O}_{2}$ \\
Kelas Kontrol & $\mathrm{O}_{3}$ & - & $\mathrm{O}_{4}$ \\
\hline Sumber: (Sugiyono, 2014) & & & \\
Keterangan : & & \\
$\mathrm{O}_{1}=$ Pretest kelas eksperimen & \\
$\mathrm{O}_{2}=$ Posttest kelas eksperimen & \\
$\mathrm{O}_{3}=$ Pretest kelas kontrol \\
$\mathrm{O}_{4}=$ Posttest kelas kontrol \\
$\mathrm{X}=$ Pembelajaran dengan menggunakan \\
pendekatan saintifik
\end{tabular}

Populasi data penelitian ini adalah seluruh siswa kelas X IPA di SMA Negeri 1 Bireuen tahun ajaran 2020/2021 yang terdiri dari 8 (Delapan) kelas. Dari 8 kelas akan di ambil 2 (dua) kelas sebagai kelas kontrol dan kelas eksperimen. Teknik pengambilan sampel memakai metode purposive sampling, dilakukan dengan beberapa pertimbangan.

Alat pengumpulan data yang digunakan adalah tes pengaruh berpikir kritis siswa yang 
dilaksanakan sebanyak dua kali yaitu tes awal (pretest) dan tes akhir (postest) dan observasi. Instrument tersebut terdiri dari soal-soal tes untuk mengukur kemampuan berpikir kritis siswa. Berikut merupakan uraian masing-masing instrument yang digunakan berupa lembar observasi aktivitas siswa dan guru. Dalam penelitian ini ada dua analisis data yang akan dirumuskan, yaitu analisis kemampuan berpikir kritis dan analisis hasil observasi.

\section{HASIL PENELITIAN DAN PEMBAHASAN}

Penelitian ini dilakukan bertujuan untuk mengetahui bahwa kemampuan berpikir kritis siswa pada materi fungsi komposisi menggunakan model pendekatan model pembelajaran saintifik memiliki pengaruh yang signifikan. Adapun untuk kelas eksperimen model pembelajaran yang diterapkan adalah model pembelajaran saintifik dan pada kelas kontrol akan digunakan model pembelajaran konvensional dengan menggunaka metode tanya jawab dan ceramah. Hal pertama dilakukan dalam penelitian adalah uji prasyarat sampel yaitu data pre-test dan yang kedua adalah uji prasyarat analisi yaitu data post test baik pada kelas eksperimen maupun kelas kontrol. Hasil yang diperoleh, yaitu data tersebut berdistribusi normal dan homogen. Hal ini menunjukkan bahwa sampel yang diambil memiliki keadaan awal yang sama. Adapun instrumen yang digunakan adalah instrumen tes essay sebanyak empat soal. Hasil penelitian dapat dilihat pada tabel berikut:

Tabel 3.1 Data Hasil Nilai Pre-Test Pada Kelas Kontrol dan Eksperimen

\begin{tabular}{ccc}
\hline \multirow{2}{*}{ Data } & \multicolumn{2}{c}{ Pre-Test } \\
\cline { 2 - 3 } & Kontrol & Eksperimen \\
\hline Jumlah siswa & 30 & 30 \\
\hline Nilai Tertinggi & 55 & 55 \\
\hline Nilai Terendah & 20 & 25 \\
\hline
\end{tabular}
Rata-rata
36,33
40,33

Tabel 3.2 Data Hasil Nilai Post-Test Pada Kelas Kontrol dan Eksperimen

\begin{tabular}{ccc}
\hline \multirow{2}{*}{ Data } & \multicolumn{2}{c}{ Post-Test } \\
\cline { 2 - 3 } & Kontrol & Eksperimen \\
\hline Jumlah Siswa & 30 & 30 \\
\hline Nilai Tertinggi & 85 & 100 \\
\hline Nilai Terendah & 60 & $\mathbf{7 0}$ \\
\hline Rata-rata & $\mathbf{7 2 , 1 7}$ & $\mathbf{8 6 , 3 3}$ \\
\hline
\end{tabular}

\section{A. Uji Prasyarat Sampel}

Penentuan Kelayakan sampel dilakukan atas perhitungan uji normalitas, uji homagenitas dan uji hipotesis dengan melakukan pretest terlebih dahulu. Adapun rinciannya adalah sebagai berikut:

\section{1) Uji Normalitas}

Uji normalitas dilakukan terhadap serangkaian data untuk mengetahui apakah populasi data berdistribusi normal atau tidak, bila data diketahui berdistribusi normal maka digunakan ujistatistik parametrik sedangkan bila data tidak berdistribusi normal maka dilakukan uji statistik non parametric (Misbahuddin \& Hasan, 2013). Adapun langkah-langkahnya yaitu sebagai berikut (Riadi \& Prabawati, 2016), 1) Input pada data view;2) Analyze; 3) descriptive statistic; 4) explore; 5) plot normal; 6) OK

Tujuan Uji normalitas yaitu untuk mengetahui apakah data yang diperoleh berdistribusi normal atau tidak. Dalam penelitian ini dilakukan dengan uji Kolmogorov Smirnov menggunakan software SPSS versi 22. Data dikatakan normal apabila Sig > a. hasil uji normalitas data pretest dapat dilihat pada tabel berikut ini: 
Tabel 3.3 Hasil Uji Normalitas Pretest Kelas Kontrol dan Eksperimen

\begin{tabular}{cccl}
\hline Statistik & Pretest & & Kesimpulan \\
\cline { 2 - 3 } & Kontrol & Eksperimen & \\
\hline A & 0,05 & 0,05 & Sig $>$ a \\
Sig & 0,84 & 0,99 & $\begin{array}{l}\text { (data } \\
\text { berdistribus } \\
\text { i normal) }\end{array}$ \\
\hline
\end{tabular}

Dari tabel terlihat bahwa hasil pengujian normalitas data pretest pada kelas kontrol dan eksperimen dengan taraf signifikan yang digunakan dalam penelitian ini yaitu sebesar $5 \%$, diperoleh bahwa sig>a. Data pretest dikelas control dan kelas eksperimen berdistribusi normal.

\section{2) Uji Homogenitas}

Pengujian homogenitas bertujuan untuk mengetahui apakah objek yang diteliti mempunyai varian yang sama (Siregar, 2017). Uji homogenitas yang digunakan dalam penelitian ini menggunakan software SPSS versi 22. Dua populasi dikatakan homogen apabila Sig $>$ a. Adapun nilai pretest yang telah dilakukan uji homogenitas dapat dilihat pada tabel 3.4 berikut:

Tabel 3.4 Hasil Uji Homogenitas Pre-test Kelas Kontrol dan Eksperimen

\begin{tabular}{|c|c|c|}
\hline Statistik & Pretest & Kesimpulan \\
\hline$A$ & 0,05 & \multirow{2}{*}{$\begin{array}{c}\text { Sig }>a \\
\text { (homogen) }\end{array}$} \\
\hline Sig & .863 & \\
\hline
\end{tabular}

Dari tabel terlihat bahwa hasil pengujian homogenitas data pretest pada kelas kontrol dan eksperimen dengan taraf signifikansi (a)=0,05 diperoleh bahwa sig>a. Hal ini menunjukkan bahwa data pretest adalah homogen.

\section{3) Uji Hipotesis}

Hipotesis digunakan untukmelihat perbandingan variabel dari rata-rata kedua sampel Uji hipotesis dilakukan setelah dilakukan uji prasyarat (Riduwan, 2009).Uji hipotesis menggunakan software versi 22 dengan uji Independent Sample Test yang bertujuan untuk menguji beda rata-rata dua kelompok dan untuk menguji pengaruh variable independen terhadap variable dependen (Trihendradi, 2010).

Uji hipotesis dilakukan dengan tujuan untuk mengetahui perbedaan nilai antara kelas control dan kelas eksprerimen. hasil uji hipotesis pretest yang telah dilakukan pada kedua kelas tersebut dapat dilihat pada tabel dibawah ini:

Tabel 3.5 Hasil Uji-t Pretest Kelas Kontrol dan Eksperimen

\begin{tabular}{ccc}
\hline \multicolumn{2}{c}{ Statistik } & Kesimpulan \\
\cline { 1 - 2 } A & 0,05 & Sig >a (tidak terdapat perbedaan \\
yang signifikan)
\end{tabular}

Dalam melakukan pengujian tersebut diajukan hipotesis sebagai berikut:

$\mathrm{H}_{0}$ : Tidak terdapat perbedaan hasil pretest antara siswa pada kelas control dan eksperimen

$\mathrm{H}_{1}$ : Terdapat perbedaan hasil pretest antara siswa pada kelas control dan eksperimen dimana, kriterianya adalah: $\mathrm{H}_{0}$ diterima jika Sig> $\alpha$; dan $\mathrm{H}_{0}$ ditolak jika Sig<a.

Diperoleh Sig > a, yaitu .364>0,05 sehingga $\mathrm{H}_{0}$ diterima, dengan demikian hasil pretest siswa antara kelas control dan eksperimen menunjukkan tidak adanya perbedaan. Artinya, dari uji hipotesis yang dilakukan pada kedua kelas yang belum mendapat perlakuan, menunjukkan kemampuan awal siswa setara atau sama antara kelas kontrol dan eksperimen sehingga sampel layak digunakan untuk penelitian.

\section{B. Uji Prasyarat Analisis Data}

Adapun rincian Uji Prasyarat analisis data adalah sebagai berikut:

\section{1) Uji Normalitas}

Adapun hitungan uji normalitas yang dilakukan pada data postest, secara umum hasil uji normalitas yang dilakukan dapat ditunjukkan dalam tabel dibawah ini: 
Tabel 3.6 Hasil Uji Normalitas Post-test Kelas Kontrol dan Eksperimen

\begin{tabular}{ccc}
\hline Statistik & Posttest & \\
\cline { 2 - 3 } & Kontrol & Eksperimen \\
\hline $\mathrm{a}$ & 0,05 & 0,05 \\
\hline Sig & .026 & .200
\end{tabular}

Kesimpulan

Sig> a (data

berdistribusi normal)

Adapun hasil pengujian normalitas data post-test pada kelas kontrol dan eksperimen dengan taraf signifikan yaitu sebesar 5\% diperoleh bahwa sig > a, dengan demikian data posttest baik dikelas control maupun kelas eksperimen berdistribusi normal.

\section{2) Uji Homogenitas}

Uji homogenitas yang telah dilakukan pada data postest, secara umum hasil uji homogenitas yang dilakukan dapat dilihata pada tabel berikut ini:

Tabel 3.7 Hasil Uji Homogenitas Post Test Kelas Kontrol dan Eksperimen

\begin{tabular}{|c|c|c|}
\hline Statistik & Posttest & Kesimpulan \\
\hline $\mathrm{A}$ & 0,05 & Sig $>a$ \\
\hline Sig & .863 & (homogen) \\
\hline
\end{tabular}

Hasil uji homogenitas data posttest pada kelas kontrol dan eksperimen dengan taraf signifikansi $(a)=0,05$ diperoleh bahwa sig $>a$, dengan demikian data posttest kedua kelas tersebut adalah homogen.

\section{3) Uji Hipotesis}

Hasil uji hipotesis data posttest untuk kelas kelas kontrol dan eksperimen dan secara umum dapat dilihat pada Tabel dibawah ini:

Tabel 3.8 Hasil Uji-t Post-Test Kelas Kontrol dan Eksperimen

\begin{tabular}{ccc}
\hline \multicolumn{2}{c}{ Statistik } & Kesimpulan \\
\cline { 1 - 2 } A & 0,05 & $\begin{array}{c}\text { Sig<a (terdapat perbedaan yang } \\
\text { signifikan) }\end{array}$ \\
\cline { 1 - 2 } Sig & 0,000 &
\end{tabular}

Dalam melakukan pengujian tersebut diajukan hipotesis berikut:

$\mathrm{H}_{0}$ : Tidak terdapat pengaruh model pembelajaran Saintifik terhadap kemampuan berpikir kritis siswa pada materi pokok fungsi komposisi

$\mathrm{H}_{1}$ : Terdapat pengaruh model pembelajaran Saintifik terhadap kemampuan berpikir kritis siswa pada materi pokok fungsi komposisi dimana kriterianya adalah:

$\mathrm{H}_{0}$ diterima jika Sig $>$ a; dan $\mathrm{H}_{0}$ ditolak jika Sig $<a$

Dari kriteria tersebut, maka diperoleh Sig < a, yaitu $0,000<0,05$ sehingga $\mathrm{H}_{0}$ ditolak dan $\mathrm{H}_{1}$ diterima. Dengan demikian terdapat perbedaan hasil postest siswa antara kelas kontrol dan eksperimen. Artinya, dari uji hipotesis yang dilakukan pada kedua kelas tersebut menunjukkan adanya pengaruh model pembelajaran Saintifik terhadap kemampuan berpikir kritis siswa pada materi fungsi komposisi pada kelas eksperimen.

Hasil uji hipotesis data post-test menunjukkan adanya penolakan $\mathrm{H}_{0}$ dan penerimaan $\mathrm{H}_{1}$ dengan demikian terdapat perbedaan rata-rata kemampuan berpikir kritis siswa pada kelas eksperimen dan kelas control, dapat disimpulkan terdapat pengaruh pendekatan model pembelajaran Saintifik terhadap kemampuan berpikir kritis siswa. penyebabnya karena terjadi perbedaan persentase rata-rata indikator kemampuan berpikir kritis pada post-test kelas eksperimen yaitu sebesar $86,33 \%$ dengan kategori sangat baik dan kelas kontrol hanya $72,17 \%$ dengan kategori baik.dengean presentase kelas eksperimen yang lebih besar sehingga model pembelajaran saintifik lebih efektif dibandingkan model konvensional. Pda kelas eksperimen, pembelajaran dirancang sesuai karakteristik pembelajaran saintifik dimana yang menjadi fokus utama masalah disajikan pada lembar kerja siswa.

Model pembelajaran saintifik dimulai dengan menyampaikan tujuan pembelajaran, apersepsi mengenai materi fungsi komposisi,kemudian selanjutnya dibagikan LKPD yang berisikan masalah yang berkaitan dengan materi yang dipelajari. LKPD berisikan beberapa pertanyaan yang berfungsi sebagai pengarah yang dapat mengasah kemampuan berpikir kritis siswa. Para siswa diberikan kesempatan yang 
sama untuk bertanya dan menjawab pertanyaan yang ada di LKPD, hali tersebut berfungsi sebagai latihan siswa agar mampu berfikir kritis dan keingintahuan yang tinggi pada pembelajaran berlangsung. Para siswa melakukan kegiatan memecahkan masalah yang diberikan guru. Hal ini akan memudahkan siswa siswa yang sulit memahami materi pelajaran. Model pembelajaran ini juga akan melatih para siswa untuk memiliki tanggung jawab atas pembelajaran sehingga dapat meningkatkan kemampuan berpikir kritis.

Kemampuan berpikir kritis siswa pada kelas kontrol masih rendah dibandikan dengan keals eksperimen. Hal ini disebabkan model pembelajaran yang diterapkan berupa tanya jawab dan ceramah. Siswa hanya mendengar penjelasan guru tanpa dilibatkan langsung pada saat pembelajaran terjadi dan siswa kurang aktif dalam belajar, siswa kurang mandiri dalam memecahkan masalah, siswa hanya hanya menerima informasi dari guru.. Siswa kurang memiliki kesempatan mengeksplorasi masalah karena pembelajaran berpusat pada guru. Dengan demikian kemampuan berpikir kritis siswa kurang meningkat. Metode Pembelajaran Konvensional menjadikan siswa lebih cepat bosan, tidak konsentrasi dalam belajar.

Nilai rata-rata sebelas indikator berpikir kritis yang diukur menunjukkan hasil post test yaitu kemampuan berpikir kritis siswa lebih baik dibandingkan dengan kelas kontrol. Indikator pencapaian kemampuan berpikir kritis siswa pada kelas ekperimen yaitu 86,33 dengan katergori sangan baik .

Analisis data hasil observasi dilakukan dengan analisis presentase. Skor yang diperoleh dari setiap indicator dijumlahkan, selanjutnya dihitung skor presentasenya dengan cara membagikan jumlah skor dengan skor maksimal dan dikalikan 100\%. Perhitungan skor presentase menggunakan rumus yang dikemukakan oleh (Arikunto, 2012) sebagai berikut:

skor persentase $(S P)=\frac{j u m l a h ~ s k o r}{j u m l a h \text { maksimal }} 100 \%$
Hasil observasi aktivitas pembelajaran yang meliputi aktivitas guru dan siswa menunjukkan bahwa aktivitas pembelajaran yang dilaksanakan pada dua kelas sudah masuk kategori yang sangat baik, denga presentase rata-rata dari dua orang pengamat terhadap aktivitas guru dalam pembelajaran di kelas eksperimen untuk pertemuan pertama dan kedua diperoleh skor presentase rata-rata sebesar $100 \%$ dan $95,71 \%$. Selanjutnya untuk aktivitas siswa di kelas eksperimen pada masing-masing pertemuan pertama dan kedua diperoleh skor presentase rata-rata sebesar $95,25 \%$, dan 95,5\%. Dan yang terakhir adalah hasil observasi aktivitas pembelajaran di kelas konvensional menunjukkan bahwa aktivitas pembelajaran yang dilaksanakan dikategorikan sangat baik. Presentase rata-rata dari dua orang pengamat terhadap aktivitas guru dalam pembelajaran di kelas pembelajaran konvensional untuk pertemuan pertama dan kedua diperoleh skor presentase rata-rata sebesar $93,75 \%$, dan $96,25 \%$. Selanjutnya untuk aktivitas siswa pada kelas konvensional pada pertemuan pertama dan kedua diperoleh skor presentase rata-rata sebesar $95 \%$, dan $91,25 \%$, termasuk dalam kategori sangat baik pula pada taraf keberhasilan pembelajaran.

\section{SIMPULAN}

Berdasarkan hasil analisis data dan pembahasan pada bab sebelumnya, dapat disimpulkan bahwa:

1. Ditemukan adanya pengaruh pendekatan model pembelajaran Saintifik terhadap kemampuan berpikir kritis siswa pada materi pokok fungsi komposisi. Perbedaan hasil tes kemampuan berpikir kritis siswa kelas eksperimen dan control yaitu hasil tes menunjukkan bahwa nilai rata-rata kelas eksperimen lebih tinggi $(86,33)$ dibandingkan dengan kelas kontrol $(72,17 \%)$.

2. Hasil observasi aktivitas pembelajaran yang meliputi aktivitas guru dan siswa menunjukkan bahwa aktivitas 
pembelajaran yang dilaksanakan pada dua kelas sudah dikategorikan sangat baik

\section{DAFTAR PUSTAKA}

Arikunto, S. (2012). Penelitian Tindakan Kelas. Bumi Aksara.

Khaulah, S., \& Novianti, N. (2019). PENERAPAN MODEL PEMBELAJARAN THINK PAIR SHARE (TPS) BERBASIS E-Khaulah, S., \& Novianti, N. (2019). PENERAPAN MODEL PEMBELAJARAN THINK PAIR SHARE (TPS) BERBASIS E-LEARNING UNTUK MENINGKATKAN KEMAMPUAN BERPIKIR KREATIF. Jurnal IImiah Pendidikan Matematika A. Jurnal IImiah Pendidikan Matematika Al Qalasadi. https://doi.org/10.32505/qalasadi.v3i2.1366

Misbahuddin, M., \& Hasan, I. (2013). Analisis data penelitian dengan statistik (Kedua). Bumi Aksara.

Pratiwi, F. ., Hairida, H., \& Rasmawan, R. (2014). Pengaruh Model Discovery Learning Dengan Pendekatan Saintifik Terhadap Keterampilan Berpikir Kritis Siswa SMA. Jurnal Pendidikan Dan Pembelajaran Khatulistiwa, Vol 3(N0 7 (2014)). https://jurnal.untan.ac.id/index.php/jpdpb/art icle/view/6488

Riadi, E., \& Prabawati, T. . (2016). Statistika Penelitian: (analisis manual dan IBM SPSS). Andi Offset.

Riduwan. (2009). Dasar dasar statistika (P. Iswara (ed.); Edisi revi). Alfabeta.

Siregar, S. (2017). Metode Penelitian Kuantitatif Dilengkapi Dengan Perhitungan Manual dan SPSS. In Metode Penelitian Kuantitatif Dilengkapi Dengan Perhitungan Manual dan SPSS.

Sugiyono. (2011). Sugiyono. 2011. Metode Penelitian Kuantitatif, Kualitatif dan R\&D. Bandung: Afabeta. Bandung:Alfabeta.

Sugiyono. (2014). Metode Penelitian Pendidikan pendekatan Kuantitatif, Kualitatif dan R\&D. In METODE PENELITIAN ILMIAH.

Syaodih, N. (2014). Penelitian Deskriptif Kualitatif. Tripven.

Trihendradi, C. (2010). Step by step SPSS 18 (S.
Suyantoro (ed.); I). Andi. 